\title{
Development of Hydrogenated Microcrystalline Silicon-Germanium Alloys for Improving Long-Wavelength Absorption in Si-Based Thin-Film Solar Cells
}

\author{
Yen-Tang Huang, Hung-Jung Hsu, Shin-Wei Liang, \\ Cheng-Hang Hsu, and Chuang-Chuang Tsai \\ Department of Photonics, National Chiao Tung University, 1001 University Road, Hsinchu 300, Taiwan \\ Correspondence should be addressed to Yen-Tang Huang; yen.tang.huang@gmail.com
}

Received 25 April 2014; Accepted 9 July 2014; Published 22 July 2014

Academic Editor: Serap Gunes

Copyright ( $) 2014$ Yen-Tang Huang et al. This is an open access article distributed under the Creative Commons Attribution License, which permits unrestricted use, distribution, and reproduction in any medium, provided the original work is properly cited.

\begin{abstract}
Hydrogenated microcrystalline silicon-germanium $\left(\mu \mathrm{c}-\mathrm{Si}_{1-x} \mathrm{Ge}_{x}: \mathrm{H}\right)$ alloys were developed for application in Si-based thin-film solar cells. The effects of the germane concentration $\left(R_{\mathrm{GeH}_{4}}\right)$ and the hydrogen ratio $\left(R_{\mathrm{H}_{2}}\right)$ on the $\mu \mathrm{c}-\mathrm{Si}_{1-x} \mathrm{Ge}_{x}: \mathrm{H}$ alloys and the corresponding single-junction thin-film solar cells were studied. The behaviors of Ge incorporation in a-Si $i_{1-x} \mathrm{Ge}_{x}: \mathrm{H}_{\text {and }} \mu \mathrm{c}-$ $\mathrm{Si}_{1-x} \mathrm{Ge}_{x}: \mathrm{H}$ were also compared. Similar to a-Si $i_{1-x} \mathrm{Ge}_{x}: \mathrm{H}$, the preferential Ge incorporation was observed in $\mu \mathrm{c}-\mathrm{Si}_{1-x} \mathrm{Ge}_{x}: \mathrm{H}$. Moreover, a higher $R_{\mathrm{H}_{2}}$ significantly promoted Ge incorporation for a-Si $\mathrm{Si}_{1-x} \mathrm{Ge}_{x}: \mathrm{H}$, while the Ge content was not affected by $R_{\mathrm{H}_{2}}$ in $\mu \mathrm{c}-\mathrm{Si}_{1-x} \mathrm{Ge}_{x}: \mathrm{H}$ growth. Furthermore, to eliminate the crystallization effect, the $0.9 \mu \mathrm{m}$ thick absorbers with a similar crystalline volume fraction were applied. With the increasing $R_{\mathrm{GeH}_{4}}$, the accompanied increase in Ge content of $\mu \mathrm{c}-\mathrm{Si}_{1-x} \mathrm{Ge}_{x}: \mathrm{H}$ narrowed the bandgap and markedly enhanced the long-wavelength absorption. However, the bias-dependent EQE measurement revealed that too much Ge incorporation in absorber deteriorated carrier collection and cell performance. With the optimization of $R_{\mathrm{H}_{2}}$ and $R_{\mathrm{GeH}_{4}}$, the single-junction $\mu \mathrm{c}-\mathrm{Si}_{1-x} \mathrm{Ge}_{x}: \mathrm{H}$ cell achieved an efficiency of $5.48 \%$, corresponding to the crystalline volume fraction of $50.5 \%$ and $\mathrm{Ge}$ content of 13.2 at.\%. Compared to $\mu \mathrm{c}$-Si:H cell, the external quantum efficiency at $800 \mathrm{~nm}$ had a relative increase by $33.1 \%$.
\end{abstract}

\section{Introduction}

Hydrogenated amorphous silicon (a-Si:H) has been widely studied $[1,2]$ and employed as an absorber in silicon thinfilm solar cells [3] because of its high absorption coefficient in the visible range of the solar spectrum and the feasibility of large area deposition. However, the solar spectrum is distributed from ultraviolet to near-infrared (IR) region. The bandgap of approximately $1.75 \mathrm{eV}$ [4] for a-Si:H limits the absorption in IR region. On the concept of light absorption, only the photons having the energies larger than the bandgap of absorbers can contribute to photoexcited carriers [5]. For effective use of the low-energy photon in the solar spectrum, the development of a lower-bandgap material is important. Accordingly, the integration of lower-bandgap material and the concept of spectrum splitting have been applied as multijunction thin-film solar cells for allowing more efficient use of solar spectrum. Compared to single-junction solar cell, the multijunction cell generally has a broadened and effective spectral response. The more efficient light absorption is attributed to the component cells with different bandgap absorbers, which leads to a higher cell efficiency. Yunaz et al. have demonstrated a potential efficiency over $20 \%$ by using AMPS-1D simulation for the Si-based multijunction thinfilm solar cell [6]. Other groups have integrated a-Si:H and hydrogenated microcrystalline silicon ( $\mu \mathrm{c}-\mathrm{Si}: \mathrm{H})$ absorbers into tandem structure cells with a stabilized efficiency over 10\% [7-9]. Moreover, Yan et al. have reported an a-Si:H/aSiGe:H/ $\mu$ c-Si:H triple-junction cell reached a recorded efficiency of $16.3 \%$ [10].

Due to a lower bandgap of $1.1 \mathrm{eV}$ [5], $\mu \mathrm{c}-\mathrm{Si}: \mathrm{H}$ has been utilized as an absorber for IR absorption [11-14]. In addition, $\mu \mathrm{c}-\mathrm{Si}: \mathrm{H}$ has a minor Staebler-Wronski effect (SWE) [14], which has less impact on the long term film quality and 
cell performance than amorphous material. Nevertheless, the indirect bandgap nature of $\mu \mathrm{c}-\mathrm{Si}: \mathrm{H}$ leads to a low absorption coefficient. Therefore, a thick $\mu \mathrm{c}-\mathrm{Si}: \mathrm{H}$ absorber is usually needed to obtain adequate IR absorption. Matsui et al. have reported that the Ge incorporation in microcrystalline silicon network led to a bandgap narrowing and an increase in IR absorption, with the consequence of a thinner $\mu \mathrm{c}-\mathrm{Si}_{1-x} \mathrm{Ge}_{x}: \mathrm{H}$ absorber in the cells [15-17]. The $\mu c-\mathrm{Si}_{1-x} \mathrm{Ge}_{x}: \mathrm{H}$ consists of an amorphous-crystalline mixed phase of binary SiGe alloys, which are affected by the deposition parameters including the hydrogen ratio $\left(R_{\mathrm{H}_{2}}\right)$ and the germane concentration $\left(R_{\mathrm{GeH}_{4}}\right)$. The addition of $\mathrm{Ge}$ to $\mathrm{Si}$ network not only lowers the bandgap, but could also reduce the crystallization of the films. The crystalline volume fraction can not only influence the electrical properties including bandgap and carrier collection, but also change the optical absorption. The trade-off between crystallization and Ge incorporation of $\mu \mathrm{c}$ $\mathrm{Si}_{1-x} \mathrm{Ge}_{x}: \mathrm{H}$ alloys should be carefully manipulated for the requirement of IR absorption.

Previous works on $\mu \mathrm{c}-\mathrm{Si}_{1-x} \mathrm{Ge}_{x}: \mathrm{H}$ alloy $[18,19]$ have reported the effect of Ge incorporation by varying $R_{\mathrm{GeH}_{4}}$ but have not yet considered the accompanied variation of crystallization. In this work, to eliminate the effect of different degree of crystallization, the $\mu \mathrm{c}-\mathrm{Si}_{1-x} \mathrm{Ge}_{x}: \mathrm{H}$ absorber with a similar crystalline volume fraction was applied to indeed discuss the effect of Ge content on cell performance. Furthermore, we compared the behaviors of the $\mathrm{Ge}$ incorporation in a$\mathrm{Si}_{1-x} \mathrm{Ge}_{x}: \mathrm{H}$ and $\mu \mathrm{c}-\mathrm{Si}_{1-x} \mathrm{Ge}_{x}: \mathrm{H}$ alloys. The effects of $R_{\mathrm{H}_{2}}$ and $R_{\mathrm{GeH}_{4}}$ on Ge incorporation were discussed.

\section{Experimental Detail}

Silicon thin films including $\mu c-\mathrm{Si}_{1-x} \mathrm{Ge}_{x}: \mathrm{H}$ were deposited by a single-chamber process in a multichamber plasmaenhanced chemical vapor deposition (PECVD) system equipped with $27.12 \mathrm{MHz} \mathrm{rf}$ power, $\mathrm{NF}_{3}$ in situ plasma cleaning, and a load-lock chamber. The films were prepared on Corning EAGLE XG glass substrate at approximately $200^{\circ} \mathrm{C}$. A gas mixture of highly $\mathrm{H}_{2}$-diluted $\mathrm{SiH}_{4}$ and $\mathrm{GeH}_{4}$ was introduced to deposit $\mu \mathrm{c}-\mathrm{Si}_{1-x} \mathrm{Ge}_{x}: \mathrm{H}$ thin films. The $R_{\mathrm{H}_{2}}$, defined as $\left[\mathrm{H}_{2}\right] /\left[\mathrm{SiH}_{4}\right]$, was varied from 71.4 to 123.0. The $R_{\mathrm{GeH}_{4}}$, defined as $\left[\mathrm{GeH}_{4}\right] /\left[\mathrm{GeH}_{4}+\mathrm{SiH}_{4}\right]$, was changed from 0 to $6.8 \%$. In contrast, the lower $R_{\mathrm{H}_{2}}$ varied from 0 to 6 and the $R_{\mathrm{GeH}_{4}}$ varied from $8.3 \%$ to $16.7 \%$ were employed for a$\mathrm{Si}_{1-x} \mathrm{Ge}_{x}: \mathrm{H}$ deposition. The film Ge content was calculated by the integrated intensities of $\mathrm{Ge} 3 d$ and $\mathrm{Si} 2 p$ core lines using the quantitative X-ray photoelectron spectroscopy (XPS) analysis [20-22]. A presputtering was conducted to eliminate contaminations and native oxides on the film surface. We have found in our previous work that the Ge content would have variation in the incubation layer. This incubation region (approximately $0.1 \mu \mathrm{m})$ occupied only small part of the absorbing layer $(\sim 0.9 \mu \mathrm{m})$. The measured Ge content shown in the paper should be representative for the absorbing layer. The crystalline volume fraction was estimated from Raman spectra, which were obtained from a high-resolution confocal Raman microscope with an excitation laser at a wavelength of $488 \mathrm{~nm}$. The dark and photocoplanar conductivities of

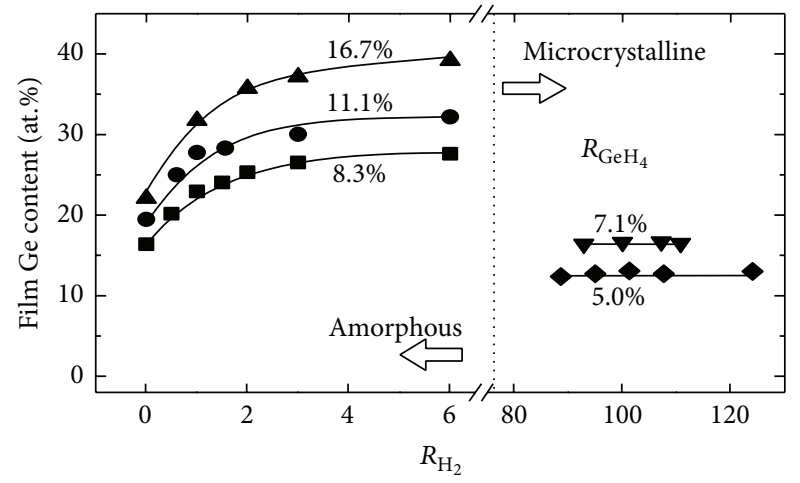

(a)

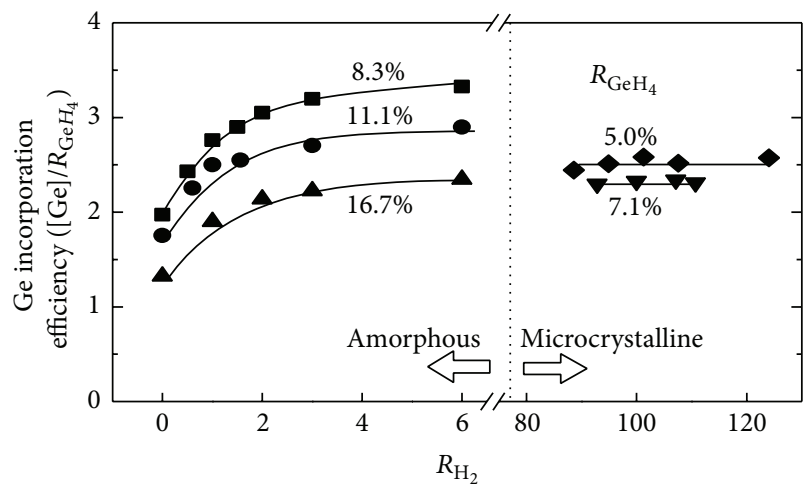

(b)

Figure 1: The variations of (a) Ge content and (b) incorporation efficiency versus $R_{\mathrm{H}_{2}}$ in amorphous [23] and microcrystalline SiGe alloys with different $R_{\mathrm{GeH}_{4}}$.

the prepared films were obtained by an $I-V$ measurement system equipped with an AM1.5G illumination. A spectrophotometer was used to determine the transmittance and the reflectance of the films. The optical bandgap $\left(E_{04}\right)$ was obtained when the absorption coefficient is $10^{4} \mathrm{~cm}^{-1}$.

The commercial textured $\mathrm{SnO}_{2}:$ F-coated substrates were utilized for preparing superstrate $\mathrm{p}-\mathrm{i}-\mathrm{n} \mu \mathrm{c}-\mathrm{Si}_{1-x} \mathrm{Ge}_{x}: \mathrm{H}$ cells. A $0.9 \mu \mathrm{m}$ thick $\mu \mathrm{c}-\mathrm{Si}_{1-x} \mathrm{Ge}_{x}: \mathrm{H}$ absorber was employed in singlejunction solar cells with a p-type $\mu \mathrm{c}$-Si:H layer and an n-type hydrogenated microcrystalline silicon oxide ( $\mu \mathrm{c}$ $\left.\mathrm{SiO}_{y}: \mathrm{H}\right)$ layer. The cell was characterized by an AM1.5G solar simulator. The area of the device for measurement was $0.25 \mathrm{~cm}^{2}$ which was defined by the silver electrode. A measuring system having monochromator, chopper, lock-in amplifier, and $I-V$ meter was applied to measure the external quantum efficiency (EQE).

\section{Results and Discussion}

3.1. Ge-Incorporation in Amorphous and Crystalline SiliconGermanium Alloys. The dependence of Ge content ([Ge]) on $R_{\mathrm{H}_{2}}$ with different $R_{\mathrm{GeH}_{4}}$ in amorphous and microcrystalline $\mathrm{SiGe}$ alloys is shown in Figure 1(a). As can be seen, the Ge content in a-Si ${ }_{1-x} \mathrm{Ge}_{x}: \mathrm{H}$ alloys rapidly increased as $R_{\mathrm{H}_{2}}$ increased from 0 to 2 at a fixed $R_{\mathrm{GeH}_{4}}$ and tended to 
saturate as $R_{\mathrm{H}_{2}}$ was larger than 2 . The phenomenon suggested that the hydrogen atoms promoted Ge incorporation in the amorphous network [23]. One possible reason may relate to the sticky nature of $\mathrm{GeH}_{3}$ species more than the $\mathrm{SiH}_{3}$ species. The diffusion length of $\mathrm{GeH}_{3}$ species is less than $\mathrm{SiH}_{3}$ species during the growth of SiGe alloy [24], which makes it more difficult to reach the energetically favorable sites on the film surface. As a result, Ge is easier to form weak bonds than $\mathrm{Si}$ in $\mathrm{SiGe}$ binary network. When the atomic hydrogen is sufficient in plasma, a high $\mathrm{H}$-coverage growth surface and local heating lead to well-relaxed network [25-27]. Thus, rigid Ge-related bonds increase as increasing hydrogen. Accordingly, more Ge atoms can be left in the films.

In high hydrogen-containing gas mixture with $R_{\mathrm{H}_{2}}$ over 2 , the saturation of Ge content was observed for a-Si ${ }_{1-x} \mathrm{Ge}_{x}: \mathrm{H}$ alloys. Presumably, the sufficient hydrogen atoms promote rigid $\mathrm{Ge}$ bonding in the films. Compared to a-Si ${ }_{1-x} \mathrm{Ge}_{x}: \mathrm{H}$ alloys, a much higher hydrogen diluted gas mixture is needed for the crystallization of the $\mu \mathrm{c}-\mathrm{Si}_{1-x} \mathrm{Ge}_{x}: \mathrm{H}$. When the $R_{\mathrm{H}_{2}}$ was over 85 at a fixed $R_{\mathrm{GeH}_{4}}$, Ge content was not significantly changed, suggesting that the effect of hydrogen for $\mathrm{Ge}$ incorporation in the $\mu \mathrm{c}-\mathrm{Si}_{1-x} \mathrm{Ge}_{x}: \mathrm{H}$ films has less impact. The resulting Ge content in the $\mu \mathrm{c}-\mathrm{Si}_{1-x} \mathrm{Ge}_{x}: \mathrm{H}$ film with increasing $R_{\mathrm{H}_{2}}$ was kept at approximately 13 and 16.7 at.\%, with $R_{\mathrm{GeH}_{4}}$ of $5.0 \%$ and $7.1 \%$, respectively.

In addition to the Ge content, the incorporation efficiency of $\mathrm{Ge}$ was also discussed. The incorporation efficiency represents the ratio of the transformation from $\mathrm{GeH}_{4}$ to film $\mathrm{Ge}$ content, defined as $[\mathrm{Ge}] / R_{\mathrm{GeH}_{4}}$. As shown in Figure 1(b), the tendency of incorporation efficiency of $\mathrm{a}-\mathrm{Si}_{1-x} \mathrm{Ge}_{x}: \mathrm{H}$ and $\mu \mathrm{c}$ $\mathrm{Si}_{1-x} \mathrm{Ge}_{x}: \mathrm{H}$ films was similar to that of the film $\mathrm{Ge}$ content with the increasing $R_{\mathrm{H}_{2}}$. The Ge incorporation efficiency was larger than one in both amorphous and microcrystalline $\mathrm{SiGe}$ alloys. This suggests that Ge was preferentially incorporated into films more than $\mathrm{Si}$. The incorporation efficiency over 1 also indicates that the change of $R_{\mathrm{GeH}_{4}}$ alters the Ge content significantly, as well as the film characteristics. One of the reasons was the less dissociation energy of $\mathrm{GeH}_{4}$ compared to $\mathrm{SiH}_{4}$. The more efficient decomposition of $\mathrm{GeH}_{4}$ was known from $\mathrm{SiH}_{4}-\mathrm{GeH}_{4}-\mathrm{H}_{2}$ discharge plasma field [28]. However, adding more $\mathrm{GeH}_{4}$ decreased the Ge incorporation efficiency. More produced sticky $\mathrm{GeH}_{3}$ precursors led to an increase in the weak Ge-related bonds [29, 30]. Consequently, under the hydrogen-containing atmospheres, the probability of the $\mathrm{SiH}_{3}$ replacement on a weak Ge-bonded site may be enhanced, which reduced the effective Ge incorporation.

In short, the preferential incorporation of $\mathrm{Ge}$ in $\mathrm{SiGe}$ alloys was observed. Compared to high $R_{\mathrm{H}_{2}}$ environment, the Ge content in SiGe alloys was affected by the hydrogen significantly in low $R_{\mathrm{H}_{2}}$ environment. More Ge content can be achieved by adding more $\mathrm{GeH}_{4}$ in the gas mixture. Nevertheless, with increasing Ge content, the incorporation efficiency of Ge into solid phase decreased with increasing $R_{\mathrm{GeH}_{4}}$.

\subsection{Effect of the Hydrogen Ratio on Film Properties and Cell} Performance. The microstructure of $\mu \mathrm{c}-\mathrm{Si}_{1-x} \mathrm{Ge}_{x}: \mathrm{H}$ films deposited with different $R_{\mathrm{H}_{2}}$ at $R_{\mathrm{GeH}_{4}}$ of $5 \%$ was studied by the Raman spectroscopy. Figure 2 shows the resulting Raman

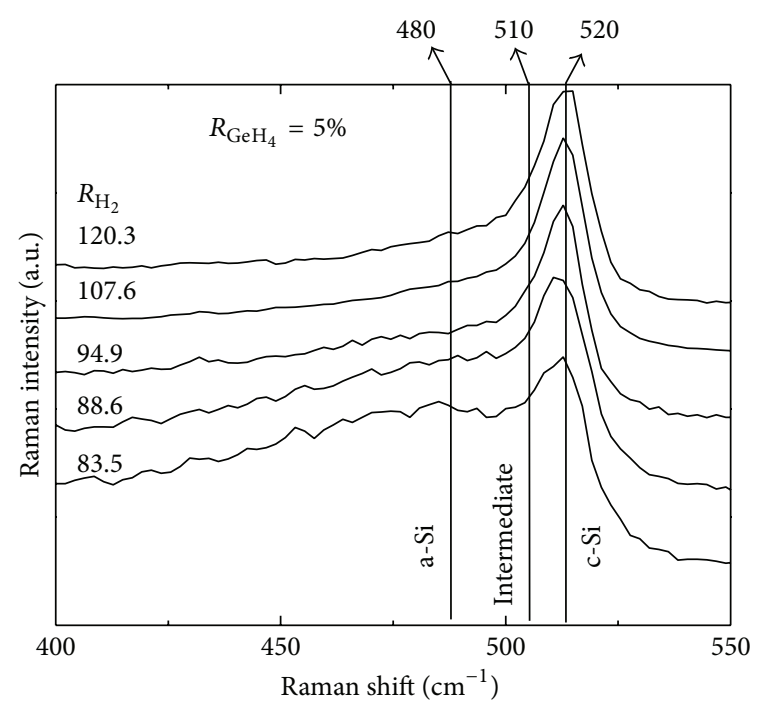

FIgURE 2: The Raman spectra of $\mu c-\mathrm{Si}_{1-x} \mathrm{Ge}_{x}: \mathrm{H}$ films with different $R_{\mathrm{H}_{2}}$.

spectra, where the transverse optical (TO) modes mainly consisted of amorphous, intermediate phase and crystalline $\mathrm{Si}-\mathrm{Si}$ networks [31]. The TO mode of amorphous Si-Si network is distributed as a Gaussian function at $480 \mathrm{~cm}^{-1}$. This is attributed to the Si-Si network in short-range order. The full width of half maximum and the Raman shift of a-Si phase are related to the variation of bonding angle of a-Si network $[32,33]$. For the narrow c-Si Lorenzian peak, the TO mode is at $520 \mathrm{~cm}^{-1}$. When the c-Si grain becomes as small as few nanometers in a crystalline-to-amorphous transition region, the Raman shift of c-Si peak decreases because of momentum conservation $[34,35]$. The peak of intermediate phase is in a Raman shift ranging approximately from 490 to $510 \mathrm{~cm}^{-1}$. This is ascribed to the defective part of the Si-Si crystallines, which include small size crystallite, bond dilation at grain boundaries, or a silicon wurtzite phase consisting of twins $[36,37]$. When the $R_{\mathrm{H}_{2}}$ increased from 83.5 to 120.3 , more crystalline phase is accompanied with less amorphous phase. However, the resulting c-Si peak constantly appeared near $512 \mathrm{~cm}^{-1}$ as increasing $R_{\mathrm{H}_{2}}$. In previous work [17, 38, 39], when Ge presents nearby the crystallites, the c-Si peak has a red-shift. In addition, the increased Ge content was in a linear correlation with decreasing c-Si peak. As mentioned in Section 3.1, Ge content was unchanged in the $\mu \mathrm{c}-\mathrm{Si}_{1-x} \mathrm{Ge}_{x}: \mathrm{H}$ films at a fixed $R_{\mathrm{GeH}}$. The higher degree of crystallization at a higher $R_{\mathrm{H}_{2}}$ is contributed to more crystallites in the films. In addition, there was no significant difference in Raman spectra at approximately $300 \mathrm{~cm}^{-1}$ for $\mu \mathrm{c}-\mathrm{SiGe}: \mathrm{H}$ samples. This may be due to a low Ge content used in this study, which contributed to negligible Ge-Ge TO mode signal from the crystal phase [40].

Effect of $R_{\mathrm{H}_{2}}$ on $X_{\mathrm{C}}$ and optical bandgap $\left(E_{04}\right)$ is shown in Figure 3. The crystalline volume fraction $\left(X_{C}\right)$ is defined by $\left(I_{520}+I_{510}\right) /\left(I_{520}+I_{510}+I_{480}\right)$, where $I_{520}, I_{510}$, and $I_{480}$ were the integrated intensities of crystalline, intermediate, and amorphous phase, respectively $[41,42]$. With a kept $R_{\mathrm{GeH}_{4}}$, 
TABLE 1: Properties of $\mu \mathrm{c}-\mathrm{Si}_{1-x} \mathrm{Ge}_{x}: \mathrm{H}$ absorber and the corresponding performance of single-junction cells with different $R_{\mathrm{H}_{2}}$ of 88.6, 94.9, 101.3, 124.1. The $R_{\mathrm{GeH}_{4}}$ of these cells was kept at 5.0\%.

\begin{tabular}{|c|c|c|c|c|c|c|}
\hline$R_{\mathrm{H}_{2}}$ & $X_{C}(\%)$ & $E_{04}(\mathrm{eV})$ & $V_{\mathrm{OC}}(\mathrm{mV})$ & $J_{\mathrm{SC}}\left(\mathrm{mA} / \mathrm{cm}^{2}\right)$ & FF (\%) & Eff. (\%) \\
\hline 88.6 & 44.0 & 1.91 & 485 & 17.17 & 58.9 & 4.90 \\
\hline 94.9 & 52.8 & 1.90 & 475 & 18.61 & 62.0 & 5.48 \\
\hline 101.3 & 59.1 & 1.89 & 460 & 18.80 & 62.4 & 5.40 \\
\hline 124.1 & 70.6 & 1.87 & 430 & 19.25 & 59.4 & 4.91 \\
\hline
\end{tabular}

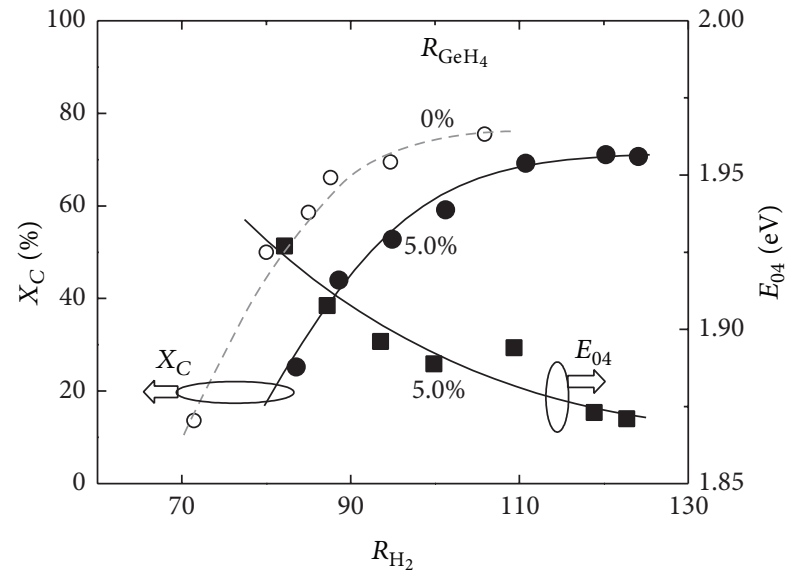

FIGURE 3: Effect of $R_{\mathrm{H}_{2}}$ on the properties of $\mu \mathrm{c}-\mathrm{Si}_{1-x} \mathrm{Ge}_{x}: \mathrm{H}$ films prepared with $R_{\mathrm{GeH}_{4}}$ of 0 and $5.0 \%$. The circle and the square symbols represent the crystalline volume fraction $\left(X_{C}\right)$ and the bandgap $\left(E_{04}\right)$, respectively.

the $X_{\mathrm{C}}$ increased with increasing $R_{\mathrm{H}_{2}}$. More $\mathrm{H}_{2}$ in the gas mixture promoted the crystallization of $\mu \mathrm{c}-\mathrm{Si}_{1-x} \mathrm{Ge}_{x}: \mathrm{H}$ growth. Moreover, given the same $X_{C}$, the $R_{\mathrm{H}_{2}}$ required for $\mu \mathrm{c}-\mathrm{Si}_{1-x} \mathrm{Ge}_{x}: \mathrm{H}$ was much larger than that for $\mu \mathrm{c}-\mathrm{Si}: \mathrm{H}$. This suggests that adding $\mathrm{GeH}_{4}$ significantly suppressed crystalline growth. This should be due to the distorted Si network by incorporating Ge, and more Ge-induced defects in the film, which needs more $\mathrm{H}$-atom to be eliminated. When $R_{\mathrm{H}_{2}}$ was varied from 83.5 to 124.1 and $R_{\mathrm{GeH}_{4}}$ was kept at $5 \%$, the $X_{C}$ increased from $25.2 \%$ to $70.6 \%$, corresponding to the decreased $E_{04}$ from 1.93 to $1.87 \mathrm{eV}$. The more crystalline phase led to a narrower bandgap, which shifted light absorption to IR. To investigate the effect of $X_{C}$ of $\mu \mathrm{c}-\mathrm{Si}_{1-x} \mathrm{Ge}_{x}: \mathrm{H}$ absorbers on cell performance, we further employed different $\mu \mathrm{c}$ $\mathrm{Si}_{1-x} \mathrm{Ge}_{x}: \mathrm{H}$ alloys as absorbers by changing the $R_{\mathrm{H}_{2}}$.

Figure 4 shows the cell structure and the $J-V$ characteristics of $\mu \mathrm{c}-\mathrm{Si}_{1-x} \mathrm{Ge}_{x}: \mathrm{H}$ p-i-n single-junction cells using absorbers prepared with different $R_{\mathrm{H}_{2}}$. This cell performance is shown in Table 1. Accompanied with the increasing $R_{\mathrm{H}_{2}}$ from 88.6 to 124.1 , the resulting bandgap narrowing of the absorber influenced the internal electric field and decreased the $V_{\text {OC }}$ from 485 to $430 \mathrm{mV}$. On the contrary, the $J_{S C}$ was significantly enhanced from 17.17 to $19.25 \mathrm{~mA} / \mathrm{cm}^{2}$. More crystalline phase in the film contributed to more photocurrent in the cells due to the lower bandgap. When the $R_{\mathrm{H}_{2}}$ was 94.9, the corresponding $X_{C}$ of the absorber was $50.5 \%$ which led to an optimal cell efficiency of $5.48 \%$.

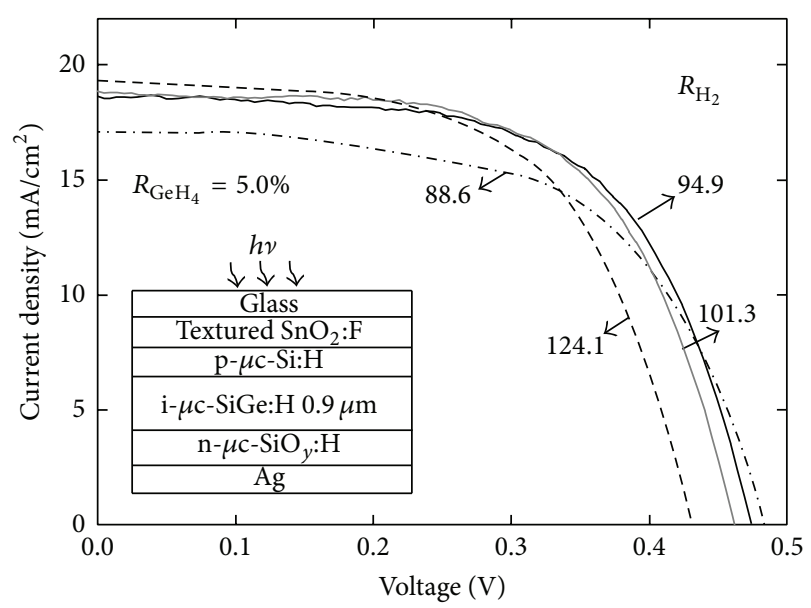

FIGURE 4: Schematic diagram of the cell structure and the $J-V$ characteristics of $\mu \mathrm{c}-\mathrm{Si}_{1-x} \mathrm{Ge}_{x}: \mathrm{H}$ solar cells with different $R_{\mathrm{H}_{2}}$ as $R_{\mathrm{GeH}_{4}}$ was $5.0 \% . R_{\mathrm{H}_{2}}=88.6$ (dot dash line), 94.9 (black line), 101.3 (gray line), and 124.1 (dash line).

3.3. Effect of the Germane Concentration on Film Properties and Cell Performance. In Section 3.1, we have shown that the $R_{\mathrm{GeH}_{4}}$ significantly changed the Ge content in the film. To reveal the effect of $R_{\mathrm{GeH}_{4}}$ on cell performance is therefore important for improving long-wavelength absorption. The $\mu \mathrm{c}-\mathrm{Si}_{1-x} \mathrm{Ge}_{x}: \mathrm{H}$ absorbers in single-junction solar cells were prepared with different $R_{\mathrm{GeH}_{4}}$ of $0,3.7 \%, 5.0 \%$, and $6.8 \%$. In addition, the $\mu \mathrm{c}-\mathrm{Si}_{1-x} \mathrm{Ge}_{x}: \mathrm{H}$ absorber with a similar $X_{\mathrm{C}}$ of approximately $55 \%$ was applied to eliminate the effect of the crystallization of absorber on the cell performance. When the $R_{\mathrm{GeH}_{4}}$ increased from 0 to $5.0 \%$, the film Ge content increased from 0 to 13.2 at.\%, as shown in Table 2. As a result, the bandgap decreased from 1.96 to $1.85 \mathrm{eV}$, corresponding to a reduction in $V_{\mathrm{OC}}$ of $90 \mathrm{mV}$. The worsened $\mathrm{FF}$ from $71.0 \%$ to $59.3 \%$ may be due to the more Ge-related defects created in the absorber with increasing Ge incorporation. With more Ge incorporation which reduced the bandgap of the absorber, the $J_{\mathrm{SC}}$ significantly increased from 17.38 to $18.50 \mathrm{~mA} / \mathrm{cm}^{2}$ due to more optical absorption. When the $R_{\mathrm{GeH}_{4}}$ was $6.8 \%$, the film Ge content further went up to 18.0 at.\%, which resulted in the degraded cell performance. The $V_{\mathrm{OC}}, \mathrm{FF}$, and $J_{\mathrm{SC}}$ decreased to $370 \mathrm{mV}, 53.0 \%$, and $17.27 \mathrm{~mA} / \mathrm{cm}^{2}$, respectively.

The improvement of $J_{\mathrm{SC}}$ according to the change of Ge content can be revealed by the EQE measurement. As shown in Figure 5, no significant drop in spectral response in short-wavelength region was observed as the $R_{\mathrm{GeH}_{4}}$ increased from 0 to $5 \%$, while the spectral response in the range of 
TABLE 2: Properties of $\mu \mathrm{c}-\mathrm{Si}_{1-x} \mathrm{Ge}_{x}: \mathrm{H}$ absorber and the corresponding performance of single-junction cells with different $R_{\mathrm{GeH}}$ of $0,3.7 \%$, $5 \%$, and $6.8 \%$. The $X_{C}$ of these cells was kept at approximately $55 \%$.

\begin{tabular}{lcccccccc}
\hline$R_{\mathrm{GeH}_{4}}$ & $R_{\mathrm{H}_{2}}$ & {$[\mathrm{Ge}]($ at.\%) } & $E_{04}(\mathrm{eV})$ & $\mathrm{QE}_{800 \mathrm{~nm}}(\%)$ & $V_{\mathrm{OC}}(\mathrm{mV})$ & $J_{\mathrm{SC}}\left(\mathrm{mA} / \mathrm{cm}^{2}\right)$ & $\mathrm{FF}(\%)$ & $\mathrm{Eff.}(\%)$ \\
\hline 0 & 81.0 & 0 & 1.96 & 26.6 & 540 & 490 & 17.38 & 71.0 \\
3.7 & 104.8 & 8.8 & 1.89 & 28.3 & 36.16 & 62.2 \\
5.0 & 109.5 & 13.2 & 1.85 & 35.4 & 360 & 18.50 & 5.23 \\
6.8 & 166.1 & 18.0 & 1.83 & 31.0 & 370 & 17.27 & 59.3 \\
\hline
\end{tabular}

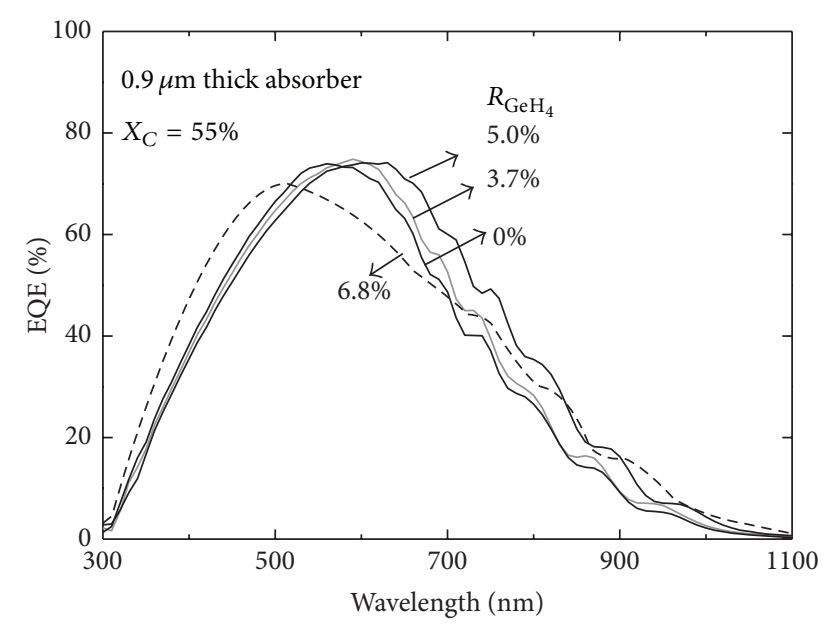

FIGURE 5: The spectral response of $\mu \mathrm{c}-\mathrm{Si}_{1-x} \mathrm{Ge}_{x}: \mathrm{H}$ p-i-n solar cells. The $\mu \mathrm{c}-\mathrm{Si}_{1-x} \mathrm{Ge}_{x}: \mathrm{H}$ absorbers were prepared with the $R_{\mathrm{GeH}_{4}}$ of $0 \%$ (black fine line), 3.7\% (gray bold line), 5\% (black bold line), and 6.8\% (dash line).

600-1100 nm was enhanced. The external quantum efficiency at $800 \mathrm{~nm}$ increased from $26.6 \%$ to $35.4 \%$. This relative increase of $33.1 \%$ in spectral response suggested that $\mathrm{Ge}$ incorporation effectively enhances the optical absorption in the infrared region. However, the red-to-IR response reduced as the absorber was prepared with $R_{\mathrm{GeH}_{4}}$ of $6.8 \%$. Too much $\mathrm{Ge}$ incorporation could degrade the transport of carriers generated in the long-wavelength region, which will be discussed in the next section. Besides, when the $R_{\mathrm{GeH}_{4}}$ was $6.8 \%$, the $\mu \mathrm{c}-\mathrm{Si}_{1-x} \mathrm{Ge}_{x}: \mathrm{H}$ absorber near $\mathrm{p} / \mathrm{i}$ interface may preferentially grow in amorphous phase. Compared to microcrystalline phase, amorphous phase generally has higher short-wavelength absorption. As a result, the increase in the spectral response range of 300-500 $\mathrm{nm}$ was observed.

The results of EQE measurement for the $\mu \mathrm{c}-\mathrm{Si}_{1-x} \mathrm{Ge}_{x}: \mathrm{H}$ cells having absorber prepared with $R_{\mathrm{GeH}_{4}}$ of $5.0 \%$ and $6.8 \%$ were presented in Figure 6 . The spectral response was measured under 0 and -2 bias voltages to reveal the difference in carrier transport. If a reverse voltage bias of $-2 \mathrm{~V}$ was applied to the device, the electric built-in field can be enlarged and the photogenerated carriers trapped by the defects can be driven out. If the cell having defects was measured with the reverse bias, the spectral response would be enlarged. For the $\mu \mathrm{c}-\mathrm{Si}_{1-x} \mathrm{Ge}_{x}: \mathrm{H}$ cell employing the absorber prepared by $R_{\mathrm{GeH}_{4}}$ of $6.8 \%$, the difference of $J_{\mathrm{SC}}$ as measured by EQE with 0 and -2 bias voltages was $1.05 \mathrm{~mA} / \mathrm{cm}^{2}$. In comparison, the
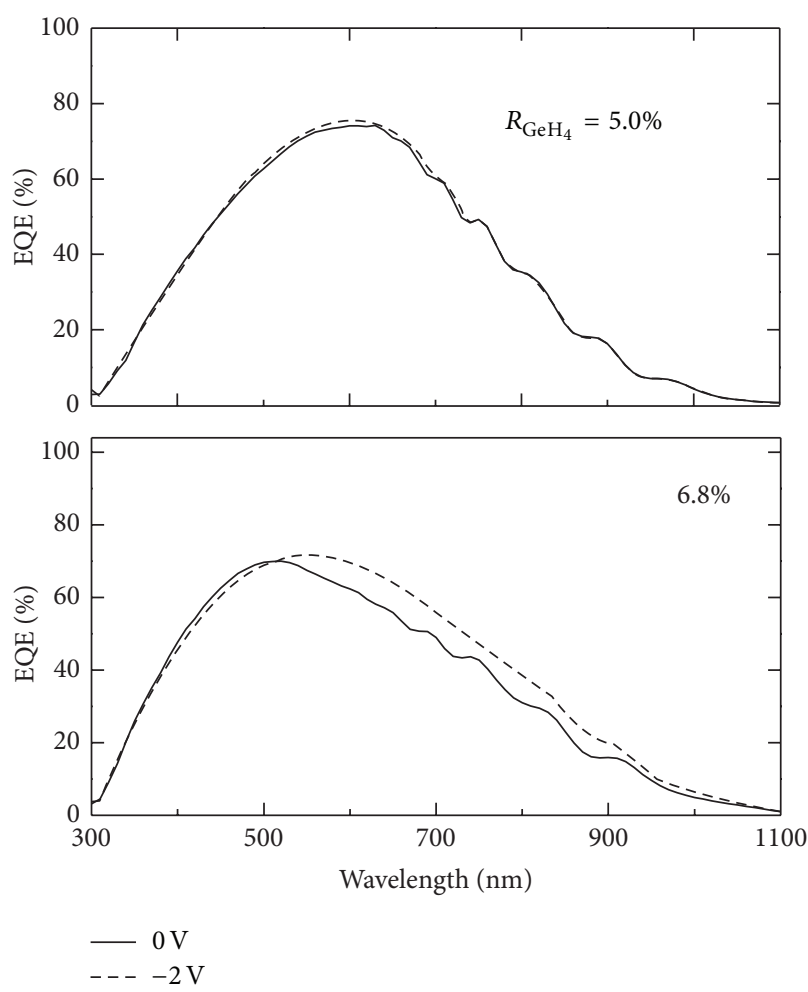

Figure 6: Spectral response of $\mu \mathrm{c}-\mathrm{Si}_{1-x} \mathrm{Ge}_{x}: \mathrm{H}$ cell measured with (dash line) and without (solid line) bias voltage. The absorbers were prepared with $R_{\mathrm{GeH}_{4}}$ of $5.0 \%$ and $6.8 \%$.

difference of $J_{\mathrm{SC}}$ for $\mu \mathrm{c}-\mathrm{Si}_{1-x} \mathrm{Ge}_{x}: \mathrm{H}$ cell employing absorber prepared with $R_{\mathrm{GeH}_{4}}$ of $5.0 \%$ under the same bias voltages was less than $0.25 \mathrm{~mA} / \mathrm{cm}^{2}$. The result indicates that too much Ge incorporation would lead to the degraded carrier collection and worsen cell performance. Moreover, in contrast to the photogenerated electrons, the holes generated by long-wavelength photons near back contact would drift toward longer distance. The change in spectral response was presumably due to the degraded hole collection [43].

\section{Conclusion}

The effects of $R_{\mathrm{GeH}_{4}}$ and $R_{\mathrm{H}_{2}}$ on $\mu \mathrm{c}-\mathrm{Si}_{1-x} \mathrm{Ge}_{x}: \mathrm{H}$ alloys and the corresponding single-junction cells were studied. Similar to $\mathrm{a}-\mathrm{Si}_{1-x} \mathrm{Ge}_{x}: \mathrm{H}$, the preferential Ge incorporation was observed in $\mu \mathrm{c}-\mathrm{Si}_{1-x} \mathrm{Ge}_{x}: \mathrm{H}$. Moreover, a higher $R_{\mathrm{H}_{2}}$ significantly promoted $\mathrm{Ge}$ incorporation for a-Si ${ }_{1-x} \mathrm{Ge}_{x}: \mathrm{H}$, while the Ge content was not affected by $R_{\mathrm{H}_{2}}$ in $\mu \mathrm{c}-\mathrm{Si}_{1-x} \mathrm{Ge}_{x}: \mathrm{H}$ 
growth. To eliminate the crystallization effect, the $0.9 \mu \mathrm{m}$ thick absorbers with a similar crystalline volume fraction were applied. With the increasing $R_{\mathrm{GeH}_{4}}$, the accompanied increase in $\mathrm{Ge}$ content of $\mu \mathrm{c}-\mathrm{Si}_{1-x} \mathrm{Ge}_{x}: \mathrm{H}$ narrowed the bandgap and edly enhanced the long-wavelength absorption. When the $R_{\mathrm{GeH}_{4}}$ increased from 0 to $5 \%$, the spectral response at $800 \mathrm{~nm}$ was significantly improved from $26.6 \%$ to $35.4 \%$, which was a relative increase by $33.1 \%$. However, the biasdependent EQE measurement revealed that too much Ge incorporation in absorber deteriorated carrier collection and cell performance. With the optimization of $R_{\mathrm{H}_{2}}$ and $R_{\mathrm{GeH}_{4}}$, the single-junction $\mu \mathrm{c}-\mathrm{Si}_{1-x} \mathrm{Ge}_{x}: \mathrm{H}$ cell achieved an efficiency of $5.48 \%$, corresponding to the crystalline volume fraction of $50.5 \%$ and $\mathrm{Ge}$ content of 13.2 at.\%. Future work will include the application of $\mu \mathrm{c}-\mathrm{Si}_{1-x} \mathrm{Ge}_{x}: \mathrm{H}$ absorbers in the tandem cell structure.

\section{Conflict of Interests}

The authors declare that there is no conflict of interests regarding the publication of this paper.

\section{Acknowledgment}

This work was sponsored by National Science Council in Taiwan under Contract no. NSC-102-3113-P-008-001 and no. NSC-2221-E-009-122.

\section{References}

[1] W. E. Spear and P. G. Le Comber, "Substitutional doping of amorphous silicon," Solid State Communications, vol. 17, no. 9, pp. 1193-1196, 1975.

[2] C. C. Tsai, J. C. Knights, G. Chang, and B. Wacker, "Film formation mechanisms in the plasma deposition of hydrogenated amorphous silicon," Journal of Applied Physics, vol. 59, no. 8, pp. 2998-3001, 1986.

[3] D. E. Carlson and C. R. Wronski, "Amorphous silicon solar cell," Applied Physics Letters, vol. 28, no. 11, article 671, 1976.

[4] M. A. Green, Solar Cells: Operating Principles, Technology and System Applications, University of New South Wales, Sydney, Australia, 1998.

[5] M. A. Green, "Third generation photovoltaics: solar cells for 2020 and beyond," Physica E: Low-dimensional Systems and Nanostructures, vol. 14, pp. 65-70, 2002.

[6] I. A. Yunaz, A. Yamada, and M. Konagai, "Theoretical analysis of amorphous silicon alloy based triple junction solar cells," Japanese Journal of Applied Physics, vol. 46, p. L1152, 2007.

[7] J. Meier, J. Spitznagel, S. Fay et al., "Enhanced light-trapping for micromorph tandem solar cells by LP-CVD $\mathrm{ZnO}$," in Proceedings of the 29th IEEE Photovoltaic Specialists Conference (PVSC '02), pp. 1118-1121, New Orleans, La, USA, May 2002.

[8] K. Yamamoto, A. Nakajima, M. Yoshimi et al., "A high efficiency thin film silicon solar cell and module," Solar Energy, vol. 77, no. 6, pp. 939-949, 2004.

[9] J. Meier, S. Dubail, R. Flückiger, D. Fischer, H. Keppner, and A. Shah, in Proceedings of the 1st World Conference on Photovoltaic Energy Conversion (WCPEC '94), p. 409, Waikoloa, Hawaii, USA, 1994.
[10] B. Yan, G. Yue, L. Sivec, J. Yang, S. Guha, and C.-S. Jiang, "Innovative dual function $\mathrm{nc}-\mathrm{SiO}_{x}: \mathrm{H}$ layer leading to a $>16 \%$ efficient multi-junction thin-film silicon solar cell," Applied Physics Letters, vol. 9, Article ID 113512, 2011.

[11] J. Meier, R. Flückiger, H. Keppner, and A. Shah, "Complete microcrystalline $p-i-n$ solar cell-crystalline or amorphous cell behavior?" Applied Physics Letters, vol. 65, p. 860, 1994.

[12] A. V. Shah, J. Meier, E. Vallat-Sauvain et al., "Material and solar cell research in microcrystalline silicon," Solar Energy Materials and Solar Cells, vol. 78, no. 1-4, pp. 469-491, 2003.

[13] K. Saito, M. Sano, S. Okabe, S. Sugiyama, and K. Ogawa, "Microcrystalline silicon solar cells fabricated by VHF plasma CVD method," Solar Energy Materials and Solar Cells, vol. 86, no. 4, pp. 565-575, 2005.

[14] B. Yan, G. Yue, X. Xu, J. Yang, and S. Guha, "High efficiency amorphous and nanocrystalline silicon solar cells," Physica Status Solidi A: Applications and Materials Science, vol. 207, no. 3, pp. 671-677, 2010.

[15] T. Matsui, M. Kondo, K. Ogata, T. Ozawa, and M. Isomura, "Influence of alloy composition on carrier transport and solar cell properties of hydrogenated microcrystalline silicon-germanium thin films," Applied Physics Letters, vol. 89, Article ID 142115, 2006

[16] T. Matsui, K. Ogata, M. Isomura, and M. Kondo, "Microcrystalline silicon-germanium alloys for solar cell application: growth and material properties," Journal of Non-Crystalline Solids, vol. 352, no. 9-20, pp. 1255-1258, 2006.

[17] G. Ganguly, T. Ikeda, T. Nishimiya, K. Saitoh, M. Kondo, and A. Matsuda, "Hydrogenated microcrystalline silicon germanium: a bottom cell material for amorphous silicon-based tandem solar cells," Applied Physics Letters, vol. 69, no. 27, pp. 42244226, 1996.

[18] T. Matsui, C. W. Chang, T. Takada, M. Isomura, H. Fujiwara, and M. Kondo, "Microcrystalline $\mathrm{Si}_{1-x} \mathrm{Ge}_{x}$ solar cells exhibiting enhanced infrared response with reduced absorber thickness," Applied Physics Express, vol. 1, no. 3, Article ID 031501, 2008.

[19] T. Matsui, K. Ogata, C. W. Chang, M. Isomura, and M. Kondo, "Carrier collection characteristics of microcrystalline silicon-germanium p-i-n junction solar cells," Journal of NonCrystalline Solids, vol. 354, no. 19-25, pp. 2468-2471, 2008.

[20] G. Lucovsky, S. S. Chao, J. E. Tyler, and G. De Maggio, "An XPS study of sputtered $a-\mathrm{Si}, \mathrm{Ge}$ alloys," Journal of Vacuum Science \& Technology A, vol. 21, p. 838, 1982.

[21] M. P. Seah, "The quantitative analysis of surfaces by XPS: a review," Surface and Interface Analysis, vol. 2, p. 222, 1980.

[22] M. P. Seah, "XPS reference procedure for the accurate intensity calibration of electron spectrometers-results of a BCR intercomparison co-sponsored by the VAMAS SCA TWA," Surface and Interface Analysis, vol. 20, no. 3, pp. 243-266, 1993.

[23] C. M. Wang, Y. T. Huang, K. H. Yen et al., "Influence of hydrogen on the germanium incorporation in a- $\mathrm{Si}_{1-x} \mathrm{Ge}_{x}: \mathrm{H}$ for thin-film solar cell application," MRS Proceedings, vol. 1245, 2010.

[24] A. R. Middya, S. C. de, and S. Ray, "Improvement in the properties of a-SiGe:H films: roles of deposition rate and hydrogen dilution," Journal of Applied Physics, vol. 73, no. 9, pp. 46224630, 1993.

[25] A. Matsuda, "Growth mechanism of microcrystalline silicon obtained from reactive plasmas," Thin Solid Films, vol. 337, no. 1-2, pp. 1-6, 1999.

[26] A. Matsuda, "Formation kinetics and control of microcrystallite in $\mu \mathrm{c}-\mathrm{Si}: \mathrm{H}$ from glow discharge plasma," Journal of NonCrystalline Solids, vol. 59-60, no. 2, pp. 767-774, 1983. 
[27] S. Veprek, Z. Iqbal, and F.-A. Sarott, "A thermodynamic criterion of the crystalline-to-amorphous transition in silicon," Philosophical Magazine B, vol. 45, no. 1, pp. 137-145, 1982.

[28] M. Stutzmann, R. A. Street, C. C. Tsai, J. B. Boyce, and S. E. Ready, "Structural, optical, and spin properties of hydrogenated amorphous silicon-germanium alloys," Journal of Applied Physics, vol. 66, no. 2, pp. 569-592, 1989.

[29] A. Morimoto, T. Miura, M. Kumeda, and T. Shimizu, "ESR and IR studies on a- $\mathrm{Si}_{1-x} \mathrm{Ge}_{x}: \mathrm{H}$ prepared by glow discharge decomposition," Japanese Journal of Applied Physics, vol. 20, no. 11, article L833, 1981.

[30] W. Paul, D. K. Paul, B. von Roedern, J. Blake, and S. Oguz, "Preferential attachment of $\mathrm{H}$ in amorphous hydrogenated binary semiconductors and consequent inferior reduction of pseudogap state density," Physical Review Letters, vol. 46, no. 15, pp. 1016-1020, 1981.

[31] D. Han, J. D. Lorentzen, J. Weinberg-Wolf, L. E. McNeil, and Q. Wang, "Raman study of thin films of amorphous-tomicrocrystalline silicon prepared by hot-wire chemical vapor deposition," Journal of Applied Physics, vol. 94, no. 5, pp. 29302936, 2003.

[32] L. Houben, M. Luysberg, P. Hapke, R. Carius, F. Finger, and H. Wagner, "Structural properties of microcrystalline silicon in the transition from highly crystalline to amorphous growth," Philosophical Magazine A, vol. 77, pp. 1447-1460, 1998.

[33] R. L. C. Vink, G. T. Barkema, and W. F. Van Der Weg, "Raman spectra and structure of amorphous Si," Physical Review B, vol. 63, no. 11, Article ID 115210, pp. 1152101-1152106, 2001.

[34] S. Veprek, F.-A. Sarott, and Z. Iqbal, "Effect of grain boundaries on the Raman spectra, optical absorption, and elastic light scattering in nanometer-sized crystalline silicon," Physical Review $B$, vol. 36, no. 6, pp. 3344-3350, 1987.

[35] Y.-L. He, C.-Z. Yin, G.-X. Cheng, L.-C. Wang, X. Liu, and G. Y. $\mathrm{Hu}$, "The structure and properties of nanosize crystalline silicon films," Journal of Applied Physics, vol. 75, no. 2, p. 797, 1994.

[36] M. Islam and S. Kumar, "Influence of crystallite size distribution on the micro-Raman analysis of porous Si," Applied Physics Letters, vol. 78, p. 715, 2001.

[37] M. Luysberg, P. Hapke, R. Carius, and F. Finger, "Structure and growth of hydrogenated microcrystalline silicon: Investigation by transmission electron microscopy and Raman spectroscopy of films grown at different plasma excitation frequencies," Philosophical Magazine A, vol. 75, no. 1, pp. 31-47, 1997.

[38] M. I. Alonso and K. Winer, "Raman spectra of c-Si $i_{1-x} \mathrm{Ge}_{x}$ alloys," Physical Review B, vol. 39, Article ID 10056, 1989.

[39] T. S. Perova, J. Wasyluk, K. Lyutovich et al., "Composition and strain in thin $\mathrm{Si}_{1-x} \mathrm{Ge}_{x}$ virtual substrates measured by microRaman spectroscopy and x-ray diffraction," Journal of Applied Physics, vol. 109, no. 3, Article ID 033502, 2011.

[40] M. Krause, H. Stiebig, R. Carius, U. Zastrow, H. Bay, and H. Wagner, "Structural and optoelectronic properties of microcrystalline silicon germanium," Journal of Non-Crystalline Solids, vol. 299-302, no. 1, pp. 158-162, 2002.

[41] J. K. Rath, M. Brinza, Y. Liu, A. Borreman, and R. E. I. Schropp, "Fabrication of thin film silicon solar cells on plastic substrate by very high frequency PECVD," Solar Energy Materials and Solar Cells, vol. 94, no. 9, pp. 1534-1541, 2010.

[42] T. Kaneko, M. Wakagi, K. Onisawa, and T. Minemura, "Change in crystalline morphologies of polycrystalline silicon films prepared by radio-frequency plasma-enhanced chemical vapor deposition using $\mathrm{SiF}_{4}+\mathrm{H}_{2}$ gas mixture at $350^{\circ} \mathrm{C}$," Applied Physics Letters, vol. 64, p. 1865, 1994.
[43] S. Guha, J. Yang, A. Pawlikiewicz, T. Glatfelter, R. Ross, and S. R. Ovshinsky, "Band-gap profiling for improving the efficiency of amorphous silicon alloy solar cells," Applied Physics Letters, vol. 54, no. 23, pp. 2330-2332, 1989. 

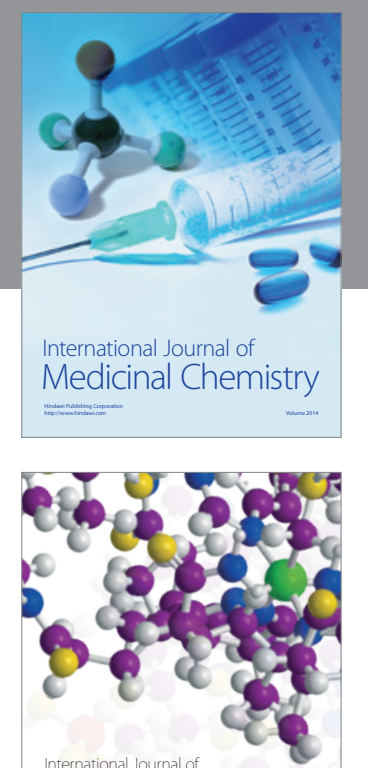

\section{Carbohydrate} Chemistry

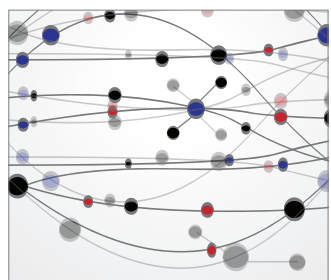

The Scientific World Journal
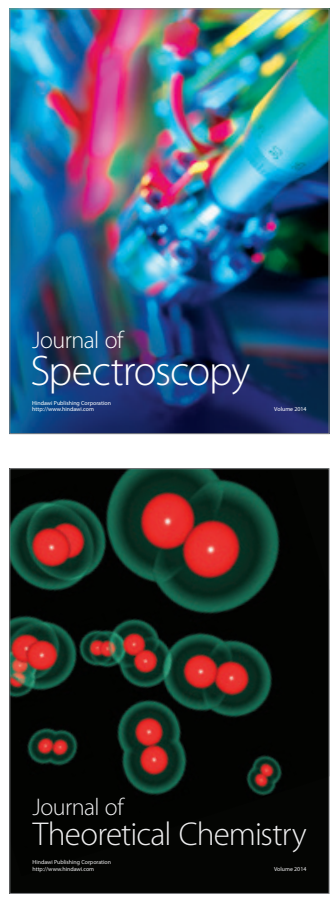
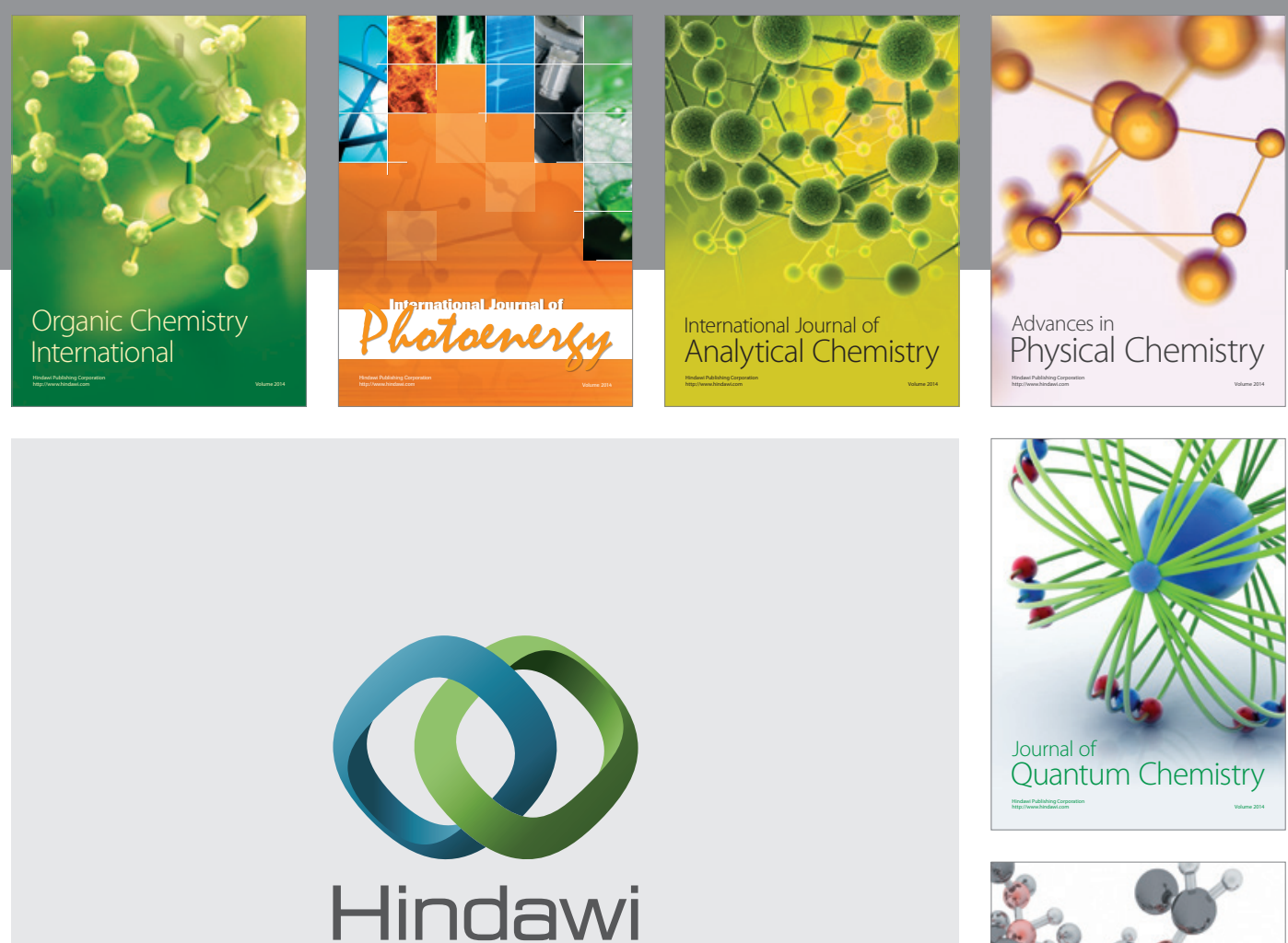

Submit your manuscripts at

http://www.hindawi.com

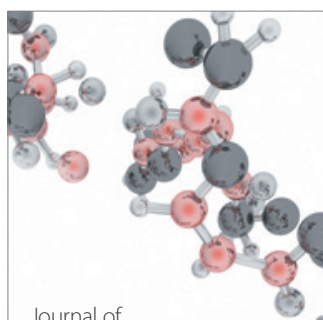

Analytical Methods

in Chemistry

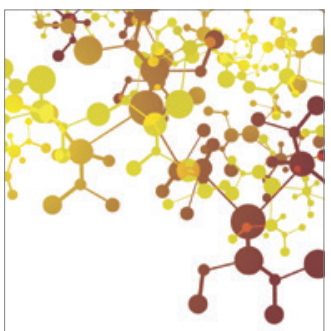

Journal of

Applied Chemistry

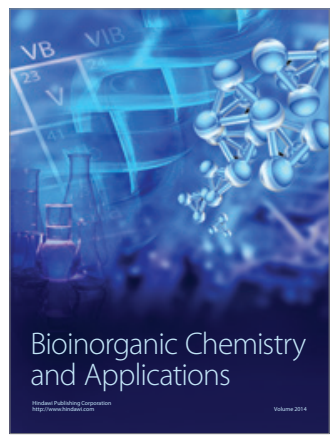

Inorganic Chemistry
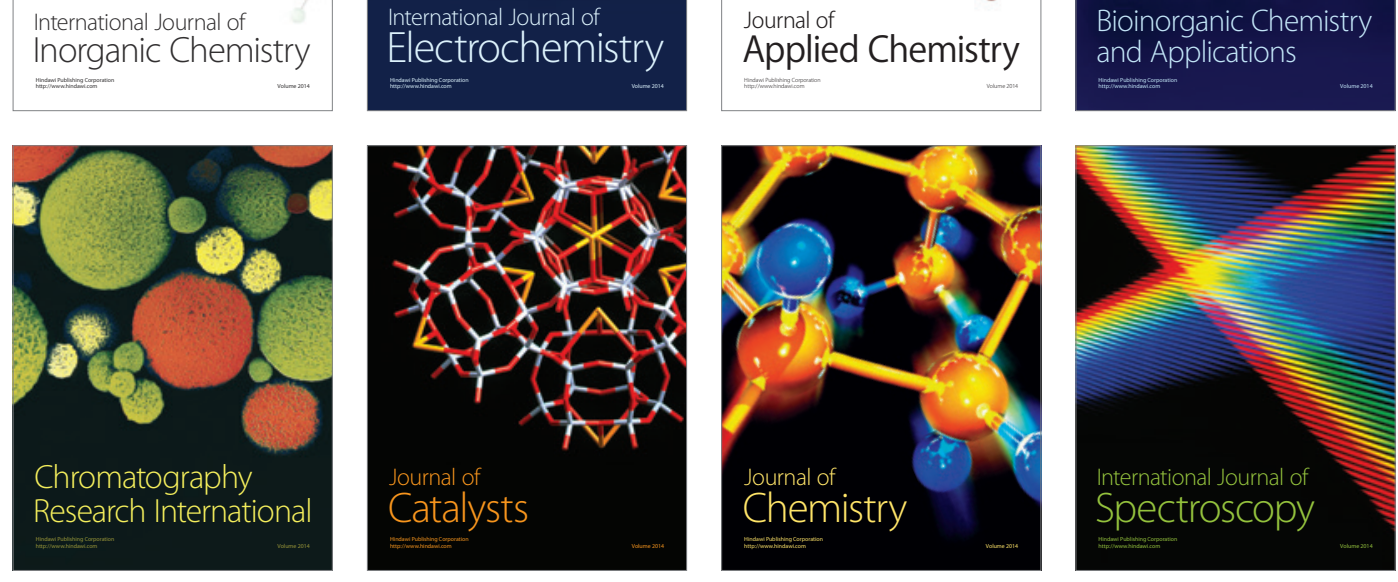